\title{
Efficacy of AZM therapy in patients with gingival overgrowth induced by Cyclosporine A: a systematic review
} Marco Clementini ${ }^{1}$, Gianluca Vittorini ${ }^{1}$, Alessandro Crea ${ }^{1}$, Maria Rosaria Gualano ${ }^{2}$, Ludovica Antonella Macrì ${ }^{1}$, Giorgio Deli ${ }^{1}$ and Giuseppe La Torre*2

Address: ${ }^{1}$ Periodontology Unit, Dental Institute, Faculty of Medicine, Catholic University of the Sacred Heart-Rome, Italy and ${ }^{2}$ Epidemiology and Biostatistics Unit, Institute of Hygiene, Faculty of Medicine, Catholic University of the Sacred Heart-Rome, Italy

Email: Marco Clementini - mclementini@hotmail.com; Gianluca Vittorini - giavitt@hotmail.com; Alessandro Crea - ale.crea@tin.it; Maria Rosaria Gualano - mar.guala@gmail.com; Ludovica Antonella Macrì - ludy_79@hotmail.com; Giorgio Deli - giordeli@tin.it; Giuseppe La Torre* - giuseppe.latorre@rm.unicatt.it

* Corresponding author

Published: 16 December 2008

BMC Oral Health 2008, 8:34 doi:10.1 |86/|472-683|-8-34
Received: 18 July 2008

Accepted: 16 December 2008

This article is available from: http://www.biomedcentral.com/I472-683I/8/34

(c) 2008 Clementini et al; licensee BioMed Central Ltd.

This is an Open Access article distributed under the terms of the Creative Commons Attribution License (http://creativecommons.org/licenses/by/2.0), which permits unrestricted use, distribution, and reproduction in any medium, provided the original work is properly cited.

\begin{abstract}
Background: In daily clinical practice of a dental department it's common to find gingival overgrowth $(\mathrm{GO})$ in periodontal patients under treatment with Cyclosporine $A(C s A)$. The pathogenesis of $G O$ and the mechanism of action of Azithromycin (AZM) are unclear. A systematic review was conducted in order to evaluate the efficacy of Azithromycin in patients with gingival overgrowth induced by assumption of Cyclosporine $A$.
\end{abstract}

Methods: A bibliographic search was performed using the online databases MEDLINE, EMBASE and Cochrane Central of Register Controlled Trials (CENTRAL) in the time period between 1966 and September 2008.

Results: The literature search retrieved 24 articles; only 5 were Randomised Controlled Trials (RCTs), published in English, fulfilled the inclusion criteria. A great heterogeneity between proposed treatments and outcomes was found, and this did not allow to conduct a quantitative meta-analysis. The systematic review revealed that a 5-day course of Azithromycin with Scaling and Root Planing reduces the degree of gingival overgrowth, while a 7-day course of metronidazole is only effective on concomitant bacterial over-infection.

Conclusion: Few RCTs on the efficacy of systemic antibiotic therapy in case of GO were found in the literature review. A systemic antibiotic therapy without plaque and calculus removal is not able to reduce gingival overgrowth. The great heterogeneity of diagnostic data and outcomes is due to the lack of precise diagnostic methods and protocols about GO. Future studies need to improve both diagnostic methods and tools and adequate classification aimed to determine a correct prognosis and an appropriate therapy for gingival overgrowth. 


\section{Background}

Gingival overgrowth (GO) and gingival enlargement (GE) are terms used to indicate a pathologic increased volume of the gingiva instead of "hyperplasia" and "hypertrophy" [1], previously adopted.

Currently there are more than 20 pharmacological formulation that could be considered associated with GO [2-4]. These drugs can be divided into 3 categories: Calciumchannel blockers [5-8], anticonvulsants [9,10], immunosuppressants [11-16]. They all recognize gingival connective tissue as secondary target tissue. Reliable figures of prevalence of GO for these 3 different categories are not available in literature: table 1 shows the results of main epidemiological studies conducted in the USA.

Drug-induced GO has a multifactorial etiology [17]. The effects of the pharmacological molecules are modulated by these factors: plaque index [18] (directly correlated); gender (males are three times more sensitive); age (inversely correlated); drug's daily dose (directly correlated); HLAB37 positivity and simultaneous administration of corticosteroids or one of the 2 other categories [19]. All these factors act in various means synergistically enhancing GO [20]. The pathogenetic mechanism of drug-induced GO is still unclear. It's modulated by fibrob- lasts $[21,22]$, cytokines [23-25], matrix metalloproteinases [26].

They seem to interact in a complex network to create the typical histopathological lesion of GO: an increased volume of the gingiva due to an abnormal stroma of connective tissue with overproduction of collagen and other extracellular matrix proteins, infiltrated by plasmacells and covered by parakeratinized epithelium also projecting irregular epithelial ridges deep inside [27].

In daily clinical practice of a dental department it's common to find GO in periodontal patients under treatment with Cyclosporine A (CsA), for example in transplanted subjects [28-32].

In our study a systematic review was conducted with the aim of evaluating the efficacy of Azithromycin (AZM) in patients with GO induced by assumption of Cyclosporine A (CsA).

The review question was:

- how effective is AZM in terms of clinical outcomes in patients with GO induced by assumption of CsA?

Table I: Estimated prevalence of Drug-Associated Gingival Enlargement according to the most frequently reported prevalence rates (Informational Paper: Drug-Associated Gingival Enlargement. J periodontal 2004;75:1424-143I)

\begin{tabular}{|c|c|c|c|}
\hline Category & Pharmacologic Agent & Trade Name & Prevalence \\
\hline \multirow[t]{5}{*}{ Anticonvulsants } & Phenytoin & Dilantin & $50 \%$ \\
\hline & Sodium valproate (valproic acid) & Depakene, Depacon, Epilim, Valpro & Rare \\
\hline & Phenobarbitone & Phenobarbital, Donnatal & $<5 \%$ \\
\hline & Vigabatrin & Sabril & Rare \\
\hline & Carbamazepine & Tegretol & None reported \\
\hline Immunosuppressants & Cyclosporin & Neoral, Sandimmune & $\begin{array}{l}\text { Adults } 25-30 \% \\
\text { Children }>70 \%\end{array}$ \\
\hline \multirow[t]{6}{*}{ Calcium channel blockers } & Nifedipine & Adalat, Nifecard, Procardia, Tenif & $6-15 \%$ \\
\hline & Isradipine & DynaCirc & None reported \\
\hline & Felodipine & Agon, Felodur, Lexxel, Plendil & Rare \\
\hline & Amlodipine & Lotrel, Norvasc & Rare \\
\hline & Verapamil & Calan, Covera, Isoptin, Tarka, Verelan & $<5 \%$ \\
\hline & Diltiazem & Cardizem, Dilacor, Diltiamax, Tiazac & $5-20 \%$ \\
\hline
\end{tabular}




\section{Methods}

In accordance with Needleman [33], a protocol was developed and it included all aspects of the review methods: inclusion criteria for studies, search strategy, screening methods, data abstraction, quality assessment by two independent reviewers and data synthesis.

\section{Inclusion criteria \\ Type of studies}

Only Randomised Controlled Trials (RCTs) or systematic reviews were included because the RCT is the most appropriate design to choose for reviews of effectiveness of therapy.

\section{Subjects}

Only patients with a clinical diagnosis of GO induced by assumption of Cyclosporine A (CsA).

Type of treatment intervention: the intervention of interest is the use of Azithromycin (AZM) with and without scaling root planing (SRP); while the control groups received other systemic or local antimicrobials or placebo with and without SRP.

\section{Types of outcome measures}

Main change in clinical attachment level (CAL), mean change in probing pocket depths (PPD), changes in bleeding on probing (BOP), gingival index (GI) and plaque index (PI), changes in coronal tooth length or clinical crown length and in distance between interdental papilla and CEJ (cementum-enamel junction) were reported in this review as outcome measures.

\section{Search strategy}

A research was performed using these online databases: MEDLINE (from 1966 to September 2008) Cochrane Oral Health Group Trials Register (September 2008); Embase (from 1988 to September 2008). The search strategy was as follows: our review question was divided in its main components to develop correct search terms for the databases, establishing a hierarchical order and using "text" terms, adopted by authors in the title and abstract, and code terms, adopted by the indexer of the database; the resulting key-words were: gingival overgrowth, Cyclosporine A, Azithromycin.

Then the search using key-words was performed into 2 different ways, using Boolean operators: "(gingival overgrowth OR GO OR gingival enlargement) AND (Cyclosporine OR Cyclosporine A OR CsA) AND (Azithromycin OR AZM OR AZT)" and without using Boolean operators: "gingival overgrowth CsA Azithromycin".

The search was limited to RCT studies conducted on humans and English language articles.

\section{Selection process}

The initial selection process was realized independently by 2 researchers. The title, abstract, and key words of identified studies were screened independently by both reviewers for relevance.

No attempts were made at this time to identify studies that did not use adequate control group, because it was considered improbable that abstracts would report enough information about the setting. The subsequent selection was made to identify only articles that dealt specifically with the inclusion criteria.

\section{Quality assessment}

The methodological quality for the included studies was assessed with a predetermined appraisal form, focusing the following issues: bibliographic details, details of the study setting as method of randomisation and blindness of patients, therapist and examiners, characteristics of study population, frequency and course of the interventions, baseline and outcome measures, completeness of follow-up.

Both reviewers independently assessed the quality of each study. The strengths and weaknesses of the study design of each included study were analysed. Disagreements on validity assessment were resolved by consensus and discussion.

\section{Results}

The search identified 24 articles found in MEDLINE, 5 articles in EMBASE (already found in MEDLINE), 3 articles in Cochrane Central of Register Controlled Trials (already found in MEDLINE).

The critical analysis of these 24 papers showed that:

1. all studies are published in English language.

2. three articles don't answer to the review question because: in one the Authors try to outline a relationship between Chlamydia Pneumoniae infection and pathogenesis of increased gingival volume [34]; one study was conducted on animals [35]; in the third one the Authors suggest to treat CsA-induced gingival overgrowth administrating Tacrolimus, an alternative immunosuppressant, instead of Cyclosporine [36].

3. five are letters to editor or short communications about other previously published papers [37-41].

4. four are case reports [42-45].

5. one is a traditional review [46]. 
6. four are clinical trials [47-50].

7. two are controlled clinical trials (not randomised) $[51,52]$.

8. five are randomised controlled trials (RCTs) [53-57].

In this systematic review were included only 5 RCTs excluding the remaining 19 studies.

\section{Studies Design}

These five studies were RCTs and subjects were kidney transplant patients.

In the study published by Nash \& Zaltzman [53], the efficacy of Azithromycin was examined in a double blind randomised crossover trial. 17 patients were randomised into 2 groups: one group received placebo for 5 days and after 2 weeks AZM (500 mg day 1, and 250 days 2-5) and the other group received AZM before placebo. Outcome measures were: gingival sulcus depths, tooth length and length of interdental papilla to the CEJ of two teeth in each of the four quadrants. The first group showed immediate improvement for the three analyzed periodontal parameters (pocket depth, tooth length, distance interdental papilla-CEJ) after receiving AZM, the second group had significant improvement immediately after AZM therapy but 3 weeks after there was a deterioration of the GD (gingival sulcus depth).

Besides the pharmacological therapy reduced the amount of gum bleeding and $67 \%$ of the patients reported that the treatment was at least somewhat useful.

In the study of Mesa et al. [54] 40 adult renal transplanted patients were included in a double blinded controlled randomised study. Patients were randomised into 3 groups (A: 13 subjects received MZN $250 \mathrm{mg} 3$ times for 7 days, B: 14 subjects received AZM $500 \mathrm{mg} 2$ times/die for 7 days, C: 13 received one cap of placebo 3 times daily for 7 days). Gingival and dental area were measured and the relationship between them was considered the GO index. The pretreatment GO index was $0.895 \pm 0.16$ for group A and after 30 days GO index was $0.897 \pm 0.28$, for group B was $0.932 \pm 0.11$ and after 30 days it became $0.909 \pm 0.15$, for group $C$ was $1.073 \pm 0.32$ and at the end was $1.130 \pm$ 0.30 . After 30 days none of the patients with GO showed complete remission.

Morphometric index of GO, a particular kind of photographic analysis matching the gingival area and the tooth area, didn't show an improvement after the proposed pharmacological therapies; a 7-day course of Azytromicin or Metronidazole or placebo didn't produce statistical sig- nificative differences. Antibiotics seemed to act against bacterial over-infection and concomitant gingival inflammation.

In the study conducted by Nafar et al.[55] 25 patients were randomised into 4 groups (group 1 received systemic AZM on the first visit in the form of 6 caps, 2 on first day and 1 per day for 4 consecutive days, group 2 received placebo in the same way of group 1, group 3 received local AZM in form of oral gel for 1 week, group 4 received placebo in similar way to group 3).

Clinical parameters were bleeding on probing (BOP), GO index and plaque length (PL). Biometric parameters were probing pocket depth (PPD), crown length (CL) and stent interdental papilla (IDP).

Only BOP index showed an improvement after 2 or 6 weeks of the 4 therapies performed. But during the first visit all patients received a professional scaling and root planing using ultrasonic cavitron after the administration of 2 gr. of Amoxicillin: in this way local periodontal irritative deposits were removed. The other adopted periodontal parameters didn't show significant differences.

In the study published by Chand et al. [56] 25 patients (mean age of 17.48 years) were included in a double blinded randomised study and divided into 2 groups: the first one received AZM $500 \mathrm{mg}$ on the first day and $250 \mathrm{mg}$ days 2-5, the other group received Metronidazole (MNZ) $45 \mathrm{mg} / \mathrm{kg} /$ die divided into 3 doses daily for 7 days. Baseline gingival measurements were $12.87 \pm 0.40 \mathrm{~mm}$ for AZM group and $13.13 \pm 0.29 \mathrm{~mm}$ for MNZ group. After 24 weeks gingival measurements were $11.50 \pm 0.14 \mathrm{~mm}$ for the first group and $12.23 \pm 0.12 \mathrm{~mm}$ for the second. The most significative difference was found at 4 weeks: at this time Azytromicin group was significantly more effective than Metronidazole.

In the study published by Ramalho et al. [57] 20 renal transplanted patients with GO were enrolled and randomised into two groups: group A received AZM $500 \mathrm{mg}$ for 3 days with oral hygiene program for 30 days, while the control group received only the oral hygiene program. Outcome measures were: subjective evaluation of oral hygiene, Simplified Oral Hygiene Index (SOHI) [58] and GH index [59].

About the first outcome measure patients in both groups declared to have improved their dental condition, in fact they had less pain and bleeding. For the other outcome measures, after 15, 30 and 60 days patients in AZM group showed statistically significant improvement of SOHI and GH index. 
In the data summary table 2 patients enrolled, therapy administered, study location, study design, duration, outcomes measures and results are available.

\section{Discussion}

Analysing the eligible studies it arose heterogeneity in various aspects of studies design such as patients characteristics (mean age for example), timing of therapy and follow up, kind of therapy put in comparison (AZM with MZM or Placebo) and drug's daily dose. Also a relevant heterogeneity of diagnostic tools and outcome measures was highlighted: in every study different parameters such as pocket depth, bleeding on probing, plaque index, photographic analysis, interdental papilla height, tooth length were used to evaluate the degree of GO. Evaluating the results, the difficulty in pooling data from these selected studies was evident: consequently it was impossible to perform a meta-analysis with sensitivity analyses because the multiple differences between them and their insufficient number impaired a statistical combination of data. The only way to make sense of the different results from the selected studies was the construction of a data summary table.

Anyway, AZM, only if associated with SRP, could be considered a better way to treat GO caused by CsA therapy than MZM or placebo such as it arose considering these 5 eligible studies. In fact in the studies of Nash et al., Nafar et al. and Chand et al. subjects treated with AZM associated with calculus and plaque removal had improvement of their condition of GO with statistically significant results. In the study of Ramalho et al. AZM associated with oral hygiene program reduced GO. Only in Mesa et al.

Table 2: Studies characteristics

\begin{tabular}{|c|c|c|c|c|c|}
\hline Study & $\begin{array}{l}\text { Chand DH et al. } \\
2004\end{array}$ & Nafar M et al. 2003 & Mesa FL et al. 2003 & Nash et al. 1998 & $\begin{array}{l}\text { Ramalho et al. } \\
2007\end{array}$ \\
\hline Participants & $\begin{array}{l}25(17 \mathrm{~m}, 8 \mathrm{f}) \text { mean } \\
\text { age: } 17.5 \pm 6.06 \mathrm{ys}\end{array}$ & $\begin{array}{c}25 \text { (16 m, } 9 \text { f) mean } \\
\text { age: } 40 \text { ys } \\
\text { (range 15-60) }\end{array}$ & $\begin{array}{l}40 \text { (? m, ? f) mean age: } \\
41.4 \text { ys (range } 24-60)\end{array}$ & $\begin{array}{l}17(12 \mathrm{~m}, 5 \mathrm{f}) \text { mean } \\
\text { age : none specified }\end{array}$ & $\begin{array}{c}20 \text { (f) mean age: } 32 \pm \\
3 \text { ys }\end{array}$ \\
\hline Setting & $\begin{array}{l}\text { Cleveland Clinic } \\
\text { Found., Cincinnati } \\
\text { Children's Medical } \\
\text { Centre }\end{array}$ & $\begin{array}{c}2 \text { medical centres in } \\
\text { Teheran }\end{array}$ & $\begin{array}{l}\text { University hospital of } \\
\text { Granada }\end{array}$ & None specified & $\begin{array}{l}\text { University Ospital of } \\
\text { Sao Jose do Rio Preto }\end{array}$ \\
\hline Interventions & $\begin{array}{c}\text { A: AZM } 500 \mathrm{mg} \text { day } \\
\text { I, } 250 \mathrm{mg} \text {. days } 2-5 \\
\text { B: MNZ } 45 \mathrm{mg} / \mathrm{kg} / \mathrm{die} \text {, } \\
3 \text { doses daily for } 7 \\
\text { days. }\end{array}$ & $\begin{array}{l}\text { (All, during the first } \\
\text { visit: SRP }+2 \mathrm{~g} \\
\text { amoxicillin) } \\
\text { A: AZM } 500 \mathrm{mg} \text { day } \\
\text { I, } 250 \mathrm{mg} \text { days } 2-5 \\
\text { B: placebo for } 5 \text { days. } \\
\text { C:AZM gel } 25 \% \text { for } 7 \\
\text { days. } \\
\text { D: placebo for } 7 \text { days. }\end{array}$ & $\begin{array}{c}\text { A: MNZ } 250 \text { mg } 3 \\
\text { times/die for } 7 \text { days. } \\
\text { B: AZM } 500 \text { mg } 2 \\
\text { times/die for } 7 \text { days. } \\
\text { C: placebo } 3 \text { times/die } \\
\text { for } 7 \text { days. }\end{array}$ & $\begin{array}{c}\text { A: placebo for } 5 \text { days } \\
+ \text { (after } 2 \text { weeks) } \\
\text { AZM } 500 \text { mg day I, } \\
250 \mathrm{mg} \text { days } 2-5 \\
\text { B: AZM } 500 \text { mg day I, } \\
250 \mathrm{mg} \text { days } 2-5+ \\
\text { (after } 2 \text { weeks) } \\
\text { placebo for } 5 \text { days }\end{array}$ & $\begin{array}{c}\text { A: oral hygiene } \\
\text { program } \\
\text { B: oral hygiene } \\
\text { program + AZM } 500 \\
\text { mg for } 3 \text { days }\end{array}$ \\
\hline Study Design & Double Blind RCT & Double Blind RCT & Double Blind RCT & Double Blind RCT & $\mathrm{RCT}$ \\
\hline Length & 24 weeks & 6 weeks & 4 weeks & 12 weeks & $30-60$ days \\
\hline $\begin{array}{l}\text { Outcomes } \\
\text { measures }\end{array}$ & $\begin{array}{c}\text { Pocket Depth (mean), } \\
\text { photographs }\end{array}$ & $\begin{array}{l}\text { Bleeding on Probing, } \\
\text { GO index, Plaque } \\
\text { Length, Pocket Depth, } \\
\text { crown length, stent } \\
\text { interdental papilla }\end{array}$ & $\begin{array}{l}\text { Morphometric GO } \\
\text { index, serum } \\
\text { creatinine and } \\
\text { creatinine clearance }\end{array}$ & $\begin{array}{l}\text { Pocket Depth, tooth } \\
\text { length, length of the } \\
\text { interdental papillae to } \\
\text { the cementum enamel } \\
\text { junction, } \\
\text { questionnaire, } \\
\text { photographs }\end{array}$ & $\begin{array}{c}\text { Subjective evaluation } \\
\text { of oral hygiene } \\
\text { (questionnaire), SOHI, } \\
\text { GH index }\end{array}$ \\
\hline Results & $\begin{array}{c}\text { Baseline GO: } \\
\text { A: } 12.87+/-0.40 \mathrm{~mm} \\
\text { B: } 13.13+/-0.20 \mathrm{~mm} \\
\text { After } 24 \text { weeks: } \\
\text { A: } 11.50+/-0.14 \mathrm{~mm} \\
\text { B: } 12.23+/-0.12 \mathrm{~mm}\end{array}$ & $\begin{array}{l}\text { Significantly results } \\
\text { only for BOP. } \\
\text { Insignificant } \\
\text { differences between } \\
\text { drug and placebo } \\
\text { groups for other } \\
\text { parameters }\end{array}$ & $\begin{array}{l}\text { Not statistically } \\
\text { significant results }\end{array}$ & $\begin{array}{l}\text { Significant } \\
\text { improvement in all } 3 \\
\text { types of periodontal } \\
\text { measurements after } \\
\text { assumption of AZM }\end{array}$ & $\begin{array}{l}\text { Significant } \\
\text { improvement of SOHI } \\
\text { and } \mathrm{GH} \text { index in } \\
\text { patients in AZM group }\end{array}$ \\
\hline
\end{tabular}


study there were not significant differences using AZM instead of MZM or placebo.

One of the most recent papers on this topic [52] (Argani et al. 2006) was considered very interesting but it was not eligible because it was lacking of randomisation and blindness. In fact the Authors examined the efficacy of local Azithromycin, in the form of toothpaste, against cyclosporine-induced gingival overgrowth, reducing the patients compliance and the adverse effects of a systemic therapy.

A well-designed randomised multicentric clinical trial would be recommendable to enlarge the sample so that results could be generalized.

Anyway, the pathogenesis of GO as well as the mechanism of action of AZM still remains unclear. The great heterogeneity of diagnostic data and results in our systematic review is due to the lack in literature of complete RCTs on the efficacy of systemic antibiotic therapy of GO, mainly due to the absence of precise diagnostic methods and tools and of an adequate classification aimed to determine a correct prognosis and an appropriate therapy for GO.

\section{Future projections}

Future researches are needed to outline a correct classification and to use universally accepted, unambiguous diagnostic parameters and an ideal study design like a RCT: in this way it is possible to identify an efficacious GO management.

\section{Conclusion}

In literature there are few RCTs on the efficacy of systemic antibiotic therapy of GO and it is mainly due to the absence of precise diagnostic tools and of an adequate classification aimed to determine a correct prognosis and an appropriate therapy for GO. The pathogenesis of GO as well as the mechanism of action of AZM still remains unclear: future researches are needed.

\section{Competing interests}

The authors declare that they have no competing interests.

\section{Authors' contributions}

MC, GV, AC, LAM carried out bibliographic search and selected the articles; GD carried out the coordination; GLT and MRG participated in the design of the study and methodology.

All authors read and approved the final manuscript.

\section{References}

I. American Academy of Periodontology: Academy report (Informational paper. Drug-associated gingival enlargement). J Periodontol 2004, 75: | 424- |431.

2. Seymour R, Heasman P: Drugs, Diseases and the Periodontium. Oxford University Press, Oxford; 1992.

3. Dongari Al, Langlais RP, McDonnell HT: Drug-induced gingival overgrowth. Oral Surg Oral Med Oral Pathol 1993, 76:543-548.

4. Rees TD, Levine RA: Systemic drugs as a risk factor far periodontal disease initiation and progression. Continuing Educational Dentistry 1995, 16:20-42.

5. Barak S, Engelberg I, Hiss Z: Gingival hyperplasia caused by nifedipine: Histopathological findings. J Periodontol 1987, 58:639-642.

6. Fattore L, Stablein M, Bredfelt G, Semla T, Moran M, Doherty-Greenberg JM: Gingival hyperplasia: A side effect of nifedipine and diltiazem. Spec Care Dentist I991, I I:107-109.

7. Ellis JS, Seymour RA, Steele JG, Robertson P, Butler TJ, Thomason JM: Prevalence of gingival overgrowth induced by calcium channel blockers: A community-based study. J Periodontol 1999, 70:63-67.

8. James JA, Marley JJ, Jamal S, Campbell BA, Short CD, Johnson RW, Hull PS, Spratt H, Irwin CR, Boomer S, Maxwell AP, Linden GJ: The calcium channel blocker used with cyclosporin has an effect on gingival overgrowth. J Clin Periodontol 2000, 27: I09-I I5.

9. Casetta I, Granieri E, Desiderá M, Monetti VC, Tola MR, Paolino E, Govoni V, Calura G: Phenytoin-induced gingival overgrowth: A community-based cross-sectional study in Ferrara, Italy. Neuroepidemiology 1997, I 6:296-303.

10. Katz J, Givol N, Chaushu G, Taicher S, Shemer J: Vigabatrininduced gingival overgrowth. J Clin Periodontol 1997, 24: I80-I82.

II. Rateitschak-Pluss E, Hefti A, Lortscher R, Thiel G: Initial observation that cyclosporin-A induces gingival enlargement in man. J Clin Periodontol 1983, 10:237-246.

12. Platt JL, Ferguson RM, Sibley RK, Gajl-Peczalska KJ, Michael AF: Renal interstitial cell populations in cyclosporine nephrotoxicity: Identification using monoclonal antibodies. Transplantation 1983, 36:343-346.

13. Proceedings of the Second International Congress on Cyclosporine. Washington, DC: Grune and Stratton; 1988:I-25.

14. Myers BD, Newton L: Cyclosporine-induced chronic nephropathy: An obliterative microvascular renal injury. J Am Soc Nephrol 199I, 2(2 SuppI I):S45-S52.

15. Boltchi FE, Rees TD, lacopino AM: Cyclosporine A-induced gingival overgrowth: A comprehensive review. Quintessence International 1999, 30:775-783.

16. James JA, Boomer S, Maxwell AP, Hull PS, Short CD, Campbell BA, Johnson RW, Irwin CR, Marley JJ, Spratt H, Linden GJ: Reduction in gingival overgrowth associated with conversion from cyclosporin A to tacrolimus. J Clin Periodontol 2000, 27: | 44- | 48.

17. Hallmon WW, Rossmann JA: The role of drugs in the pathogenesis of gingival overgrowth. A collective review of current concepts. Periodontol 1999, 2 I: I76-196.

18. Fu E, Nieh S, Wikesjo UM: The effect of plaque retention on cyclosporine-induced gingival overgrowth in rats. J Periodontol 1997, 68:92-98.

19. Morisaki I, Fukui N, Fujimori Y, Murakami J, Daikoku H, Amano A: Effects of combined oral treatments with cyclosporine $A$ and nifedipine or diltiazem on drug-induced gingival overgrowth in rats. J Periodontol 2000, $71: 438-443$.

20. Thomas DW, Newcombe RG, Osborne GR: Risk factors in the development of cyclosporine-induced gingival overgrowth. Transplantation 2000, 69:522-526.

21. Hassell TM: Evidence for production of an inactive collagenase by fibroblasts from phenytoin-enlarged human gingiva. J Oral Pathol 1982, I I:310-317.

22. Johnson RB, Zebrowski EJ, Dai X: Synergistic enhancement of collagenous protein synthesis by human gingival fibroblasts exposed to nifedipine and interleukin- I-beta in vitro. J Oral Pathol Med 2000, 29:8-I2.

23. Duncan MR, Berman B: Stimulation of collagen and glycosaminoglycan production in cultured human adult dermal fibroblasts by recombinant human interleukin-6. J Invest Dermatol 1991, 97:686-689.

24. Williarnson MS, Miller EK, Plemons J, Rees T, lacopino AM: Cyclosporine A upregulates interleukin-6 gene expression in 
human gingiva: Possible mechanism for gingival overgrowth. J Periodontol 1994, 65:895-903.

25. Myrillas TI, Linden GJ, Marley JJ, Irwin CR: Cyclosporin A regulates interleukin-I beta and interleukin-6 expression in gingiva: Implications for gingival overgrowth. J Periodontol 1999 , 70:294-300.

26. Bolzani G, Della Coletta R, Martelli Junior H, Graner E: Cyclosporin $A$ inhibits production and activity of matrix metalloproteinases by gingival fibroblasts. J Periodontal Res 2000, 35:5I-58.

27. Mariani G, Calastrini C, Carinci F, Marzola R, Calura G: Ultrastructural features of CsA-induced gingival hyperplasia. J Periodontol 1993, 64:1092-1097.

28. Calne RY, White DJ, Thiru S, Evans DB, McMaster P, Dunn DC, Craddock GN, Pentlow BD, Rolles K: Cyclosporine $\mathbf{A}$ in patients receiving renal allografts from cadaver donors. Lancet 1978 , 2:1323-1327.

29. Khocht A, Schneider LC: Periodontal management or gingival overgrowth in the heart transplant patient: A case report. J Periodontol 1997, 68: I |40-1 | 46.

30. Kilpatrick NM, Weintraub RG, Lucas JO, Shipp A, Byrt T, Wilkinson $\mathrm{JL}$ : Gingival overgrowth in pediatric heart and heart-lung transplant recipients. J Heart Lung Transplant 1997, 16: I23 I-I 237.

31. Payne VM: Re: Periodontal management of gingival overgrowth in the heart transplant patient: A case report (1997; 68: I 140-I I 46). J Periodontol 1998, 69:1314-1315.

32. Varga E, LeMon MA, Mair LH: Pre-transplant gingival hyperplasia predicts severe cyclosporin-induced gingival overgrowth in renal transplant patients. I Clin Periodontol 1998, 25:225-230.

33. Needleman IG: A guide to a systematic reviews. J Clin Periodontol 2002, 29 Suppl 3:6-9: discussion 37-8.

34. Worm HC, Wirnsberger GH, Mauric A, Holzer H: High prevalence of Chlamydia pneumoniae infection in cyclosporin Ainduced post-transplant gingival overgrowth tissue and evidence for the possibility of persistent infection despite shortterm treatment with azithromycin. Nephrol Dial Transplant 2004, 19:1890-1894.

35. Paik JW, Kim CS, Cho KS, Chai JK, Kim CK, Choi SH: Inhibition of cyclosporin A-induced gingival overgrowth by azithromycin through phagocytosis: an in vivo and in vitro study. J Periodontol 2004, 75:380-7.

36. Vallejo C, Iniesta P, Moraleda JM: Resolution of cyclosporineinduced gingival hyperplasia resistant to azithromycin by switching to tacrolimus. Haematologica 200I, 86: I 10.

37. Wahlstrom E, Zamora JU, Teichman S: Improvement in cyclosporine-associated gingival Hyperplasia with azithromycin therapy. N Engl J Med 1995, 332:753-754.

38. Palomar R, Belart M, Soy D, Oppenheimer F, Campistol JM: Effectiveness and safety of azithromycin on the treatment of cyclosporine-induced gingival overgrowth. Nephron 1998, 79: $101-2$.

39. Jucgla A, Moreso F, Sais G, Gil-Vernet S, Graells J, Grinyo JM, Peyri J: The use of azithromycin for cyclosporin-induced gingival overgrowth. $\mathrm{Br}$ J Dermatol 1998, I38:198-199.

40. Wirnsberger GH, Pfragner R: Comment on "Efficacy of azithromycin in the treatment of cyclosporine-induced gingival hyperplasia in renal transplant recipients" by Nash and Zaltzman. Transplantation 1999, 67:|289-129|.

41. Verma A, Dhawan A: Re: Trial of metronidazole vs. azithromycin for treatment of cyclosporine-induced gingival overgrowth. Pediatr Transplant 2005, 9:132.

42. Boran M, Gunes Z, Doruk F, Gonenc F, Cetin S: Improvement in cyclosporine $A$ associated gingival hyperplasia with azithromycin therapy. Transplant Proc 1996, 28:2316.

43. Puig JM, Lloveras J, Bosch JM, Munne A, Mir M, Barbosa F, Masramon $\mathrm{J}$ : Treatment of gingival hyperplasia secondary to cyclosporine by the new macrolide azithromycin. Transplant Proc 1997, 29:2379-80.

44. Nowicki M, Kokot $F$, Wiecek $A$ : Partial regression of advanced cyclosporin-induced gingival hyperplasia after treatment with azithromycin. A case report. Ann Transplant 1998, 3:25-7.

45. Strachan D, Burton I, Pearson GJ: Is oral azithromycin effective for the treatment of cyclosporine-induced gingival hyperplasia in cardiac transplant recipients? J Clin Pharmacological Therapy 2003, 28:329-338.
46. Wright G, Welbury RR, Hosey MT: Cyclosporin-induced gingival overgrowth in children. International J Paediatr Dent 2005, I5:403-4II.

47. Gomez E, Sanchez-Nunez M, Sanchez JE, Corte C, Aguado S, Portal C, Baltar J, Alvarez-Grande J: Treatment of cyclosporin-induced gingival hyperplasia with azithromycin. Nephrology Dialysis. Transplantation 1997, I 2:2694-2697 [http://ndt.oxfordjournals.org/ cgi/reprint//2//2/2694]

48. Citterio F, Di Pinto A, Borzi MT, Scata MC, Foco M, Pozzetto U, Castagneto $M$ : Azithromycin treatment of gingival hyperplasia in kidney transplant recipients is effective and safe. Transplant Proc 200I, 33:2I34-5.

49. Kwun WH, Suh BY, Kwun KB: Effect of azithromycin in the treatment of cyclosporine-induced gingival hyperplasia in renal transplant recipients. Transplant Proc 2003, 35:3 | I-3 I 2 .

50. Tokgoz B, Sari HI, Yildiz O, Aslan S, Sipahioglu M, Okten T, Oymak $O$, Utas C: Effects of azithromycin on cyclosporine-induced gingival hyperplasia in renal transplant patients. Transplant Proc 2004, 36:2699-2702.

5I. Wirnsberger GH, Pfragner R, Mauric A, Zach R, Bogiatzis A, Holzer $\mathrm{H}$ : Effect of antibiotic treatment with azithromycin on cyclosporine A-induced gingival hyperplasia among renal transplant recipients. Transplant Proc 1998, 30:2117-2119.

52. Argani H, Pourabbas R, Hassanzadeh D, Masri M, Rahravi H: Treatment of cyclosporine-induced gingival overgrowth with azithromycin-containing toothpaste. Exp Clin Transplant 2006 , 4:420-424.

53. Nash MM, Zaltzman JS: Efficacy of azithromycin in the treatment of cyclosporine-induced gingival hyperplasia in renal transplant recipients. Transplantation 1998, 65:1611-1615.

54. Mesa FL, Osuna A, Aneiros J, Gonzalez-Jaranay M, Bravo J, Junco $P$ Del Moral RG, O'Valle F: Antibiotic treatment of incipient druginduced gingival overgrowth in adult renal transplant patients. J Periodontal Res 2003, 38:141-146.

55. Nafar M, Ataie R, Einollahi B, Nematizadeh F, Firoozan A, Poorrezagholi $F$ : A comparison between the efficacy of systemic and local azithromycin therapy in treatment of cyclosporine induced gingival overgrowth in kidney transplant patients. Transplant Proc 2003, 35(7):2727-2728.

56. Chand DH, Quattrocchi J, Poe SA, Terezhalmy GT, Strife CF, Cunningham RJ: Trial of metronidazole vs. azithromycin for treatment of cyclosporine-induced gingival overgrowth. Pediatr Transplant 2004, 8:60-64.

57. Ramalho VL, Ramalho HJ, Cipullo JP, Azoubel R, Burdmann EA: Comparison of azithromycin and oral hygiene program in the treatment of cyclosporine-induced gingival hyperplasia. Ren Fail 2007, 29(3):265-70.

58. Greene JC, Vermillion JR: The simplified oral hygiene index. J Am Dent Assoc 1964, 68:7-13.

59. Angelopoulos AP, Goaz PW: Incidence of diphenylhydantoin gingival hyperplasia. Oral Surg Oral Med Oral Pathol 1972, 34(6):898-906.

\section{Pre-publication history}

The pre-publication history for this paper can be accessed here:

http://www.biomedcentral.com/1472-6831/8/34/prepub 